\title{
(I)MATERIALIDADES DISCURSIVAS E EFEITOS METAFÓRICOS
}

\author{
DISCOURSE AND CINEMA: \\ NON-VERBAL (I)MMATERIALITIES AND METAPHORICAL EFFECTS
}

Tania Conceição Clemente de Souza

UFRJ - Universidade Federal do Rio de Janeiro

\begin{abstract}
RESUMO: Buscamos entender a textualização do político no âmbito do não verbal, analisando a relação de intertextualidade de duas cenas em dois filmes: a escadaria de Odessa, em $O$ Encouraçado Potemkin (1925) e a escadaria da estação de trem em Os Intocáveis (1987). Através do movimento de efeitos metafóricos, trabalha no filme de De Palma uma memória discursiva que aponta tanto a filiação de uma textualidade em termos de montagem a Eiseinstein, quanto a possibilidade de se falar de materialidades e imaterialidades não verbais.
\end{abstract}

PALAVRAS-CHAVE: cinema; materialidade discursiva não verbal; memória.

ABSTRACT: We seek to understand how the politics is expressed into the non-verbal domain by the analysis of the intertextual relation between two scenes from two movies: the Odessa steps, in Battleship Potemkin (1925) and the train station steps, in The Untouchables (1987). Through the movement of metaphorical effects, a discursive memory works in the De Palma's movie, pointing out both the filiation and the possibility to talk about non-verbal (i)mmaterialities in Eiseinstein.

KEYWORDS: cinema; non-verbal discursive materiality; memory.

"Não é que a palavra seja imperfeita e esteja, em face do visível, num déficit que em vão se esforçaria por recuperar. São irredutíveis uma ao outro."

Michel Foucault

\section{Introdução}

Há algum tempo venho refletindo sobre os modos de significação da imagem em diferentes suportes, tais como a televisão, o cinema, a publicidade e até mesmo em eventos culturais como o carnaval (Souza, 1997, 1998, 2000, 2001, 2006, 2012, etc.). O viés adotado neste percurso é o da escola francesa de Análise de Discurso. Em especial, a reflexão sobre as formas da imagem sofre grande influência do trabalho de Orlandi (1992 e 1995) sobre as formas do silêncio.

Dentre as várias questões que o enfoque discursivo da imagem suscita, está a compreensão de uma materialidade discursiva específica - a não verbal - e a sua relação com o político. Daí decorre nosso principal objetivo: buscar entender a textualização do político no âmbito do não verbal, explicitando, ao mesmo tempo, aspectos da materialidade não verbal. 
Neste trabalho, recorto como objeto a discursividade no cinema, colocando em pauta a relação de intertextualidade de duas cenas em dois filmes: a cena da escadaria de Odessa, no filme $O$ encouraçado Potemkin (Eiseinstein, 1925) e a cena da escadaria na estação de trem no filme Os intocáveis (Brian de Palma, 1987). Através do movimento de vários efeitos metafóricos, trabalha, no filme de Palma, uma memória discursiva que, uma vez explicitada, aponta, por um lado, a filiação de uma textualidade em termos de montagem a Eiseinstein. Por outro lado, os efeitos metafóricos revelam como os sentidos deslizam de um filme para o outro, abrindo a possibilidade de se falar, em termos discursivos, de materialidades e imaterialidades não verbais; traços que textualizam o político, tomado aqui como fato discursivo. Nas palavras de Orlandi (1992), o político "se define na forma de (se) significar a (na) sociedade, o (no) social, produzindo-se deferentes direções de sentido".

\section{As duas cenas}

A cena de Eiseinstein traz a história ficcional de um dos mais trágicos episódios da revolução de 1905. Trata-se da invasão dos cossacos em Odessa, que metralham as pessoas por onde passam: não poupam ninguém, nem velhos, nem crianças, nem bebês. As pessoas se atropelam na descida da grande escadaria e, à medida que vão sendo metralhadas, os corpos vão se amontoando pelos degraus. Trata-se de um trabalho altamente emocional, mas muito claro no seu enfoque político, bem como na publicização desse enfoque através do filme. Os grandes planos das faces humanas carregadas de sofrimento e do ritmo marcado das botas dos soldados na tão lendária sequência da escadaria de Odessa são tão impactantes que algumas exibições do filme fora da URSS provocaram desacatos com a polícia, já que o público estava convencido de que estava diante de um cine-jornal.

A cena de Brian de Palma se passa numa escadaria de uma estação ferroviária. Trata-se do momento clímax em que Eliot Ness, personagem encarnado por Kevin Costner, designado para pôr fim à máfia da bebida ilegal em Chicago, comandada por Al Capone, espreita os capangas que vão tentar embarcar de trem. É a cena mais famosa do filme, cujo clima de tensão é aumentado com a chegada de uma mulher com um carrinho de bebê que despenca pela escadaria no meio do tiroteio. Segundo o diretor Brian de Palma, essa cena, propositalmente, toma como referência a cena da escadaria de Odessa, cuja intenção é homenagear o diretor russo. Essa referência se faz pela citação de alguns elementos - a escadaria, a mãe desesperada, o carrinho do bebê, as expressões faciais de alguns dos personagens e outros. Além dessas citações, a montagem em si referenda a escola eiseinsteiniana que em conjunto com todas as citações ressignificam a dramaticidade e a carga emocional do filme russo.

\section{Montagem e metáfora}

Eiseinstein é considerado o mestre em montagem (métrica, rítmica, intelectual). A famosa cena da escadaria de Odessa (1925) remete ao tipo de montagem intelectual - aquela que vai jogar com uma sincronia entre planos, luz e som, dando lugar ao que, no cinema, vem sendo chamando de Metáforas.

É sabido que Brian de Palma, no filme Os intocáveis (1987) se propõe a fazer uma homenagem a Eiseinstein ressignificando a cena da escadaria de Odessa numa outra cena que se passa numa escadaria de uma estação de trem. São vários os deslizamentos de sentido 
que trabalham nessa ressignificação, dando lugar aos efeitos metafóricos. Os efeitos metafóricos são em si os efeitos produzidos com os deslizamentos de sentido. Por efeito metafórico, Pêcheux (1969) define o efeito semântico que se produz numa substituição contextual, isto é, por um deslizamento de sentido numa distância entre x e y, sendo esta constitutiva, tanto do sentido produzido por x, como por y. E é nesse jogo de deslizamentos que se instituem os movimentos de interpretação, dando lugar à produção do sentido.

Ao trabalhar com a noção de efeitos metafóricos no âmbito da imagem recorto, ao lado da noção de operador discursivo, o conceito de Policromia, como formulei em Souza (2001, p. 81):

Ao se definir policromia como rede de elementos visuais, implícitos ou
silenciados, verifica-se que são esses os elementos que possibilitarão as
diferentes interpretações do texto não verbal. Com isso, se diz que as
imagens não são visíveis, tornam-se visíveis a partir da possibilidade de cada
um projetar as imagens possíveis, que necessariamente, não compõem a
estrutura visual do texto não verbal em si, mas que compõem a rede de
imagens mostradas, indiciadas, implícitas, metaforizadas ou silenciadas. O
analista, ao se inscrever pelo viés da policromia, direciona e constrói o
próprio olhar através dos gestos de interpretação. Os gestos de interpretação
são em si efeitos metafóricos, deslizamentos de sentido, ordenados pela
injunção do dizer.

O conceito de policromia, tendo na sua base o radical grego - cromo -, se aproxima do sentido de cromolitografia, arte de estampar em relevo figuras coloridas. Recobre, portanto, o jogo de imagens, cor, luz e sombra etc. presentes na textualidade das imagens. Tal conceito foi forjado em paralelo ao conceito de polifonia (como trabalhado em Ducrot (1987), no sentido de se pensar o funcionamento dos implícitos e do silêncio na relação com o não verbal e, ainda, de se buscar entender em termos discursivos a tessitura do não verbal.

É no corpo da tessitura do não verbal, rede de associações de elementos de visibilidade, que se constitui o político, de caráter ideológico, lugar possível de se pensar a constituição da imagem como discurso: como efeito de sentidos entre interlocutores, como nos diz Pêcheux. A relação de tessitura, entremeio, indicia certas imagens que podem e devem mostrar/dizer algo, não outras possíveis, em face do que pode e deve ser dito:

O conjunto de elementos visuais que se destacam - entendidos como operadores discursivos - favorece uma rede de associações de imagens, o que dá lugar à tessitura do texto não verbal. A apreensão dessas relações, por sua vez, revela o discurso que se instaura pela imagem, independente de sua relação com qualquer palavra. (SOUZA, 2001, p. 81)

Em resumo, são esses os rasgos teóricos que norteiam boa parte da análise dos gestos discursivos projetados pelo diretor Brian de Palma. Outras reflexões serão empreendidas no decorrer da análise.

\section{Efeitos metafóricos e (i)materialidades discursivas}

A forma como operam os efeitos metafóricos no filme de Palma contribui, em muito, à análise do não verbal, no que se refere, sobretudo, à compreensão da relação de intertextualidade entre os dois filmes. Embora a comparação entre as duas cenas seja 
contingente, a associação entre essas cenas se dá de forma bastante complexa em termos de textualidade, o que me leva a explicitar o jogo entre dois tipos de materialidade: uma concreta e outra, abstrata.

Passemos à análise.

\subsection{TEMPO CRONOLÓGICO/TEMPO PSICOLÓGICO}

As duas cenas nas escadarias têm a mesma duração: em torno de 10 minutos. Essa semelhança de cronologia é marcada, sobretudo, por dois operadores discursivos:

(i) O relógio na parede, ao fundo, que anuncia a proximidade do conflito através de um movimento de câmera interessante: à medida que o momento se aproxima, os ponteiros do relógio são focalizados cada vez mais próximos, marcando aí um tempo de 10 minutos.

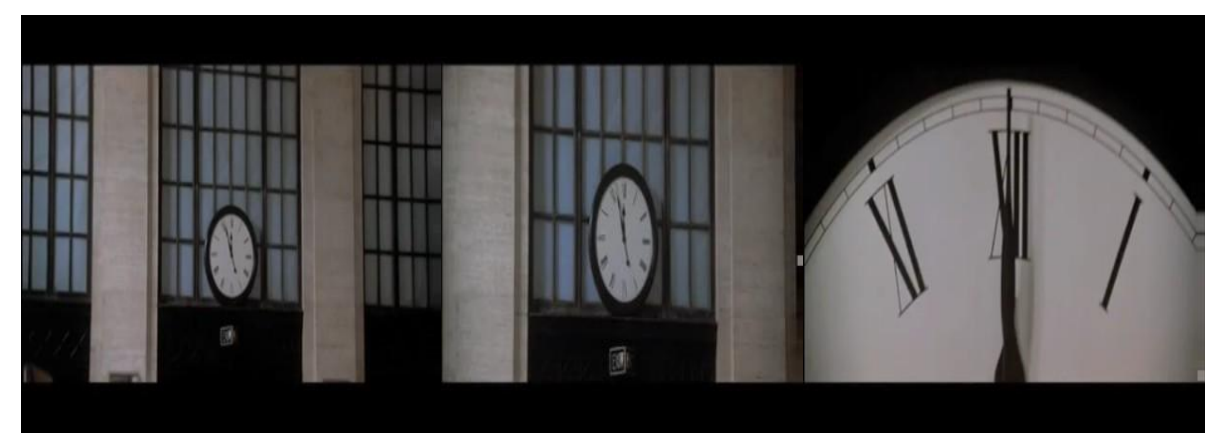

(ii) O movimento pendular da cabeça do personagem principal, que ora olha para o ambiente em si, ora para o relógio.

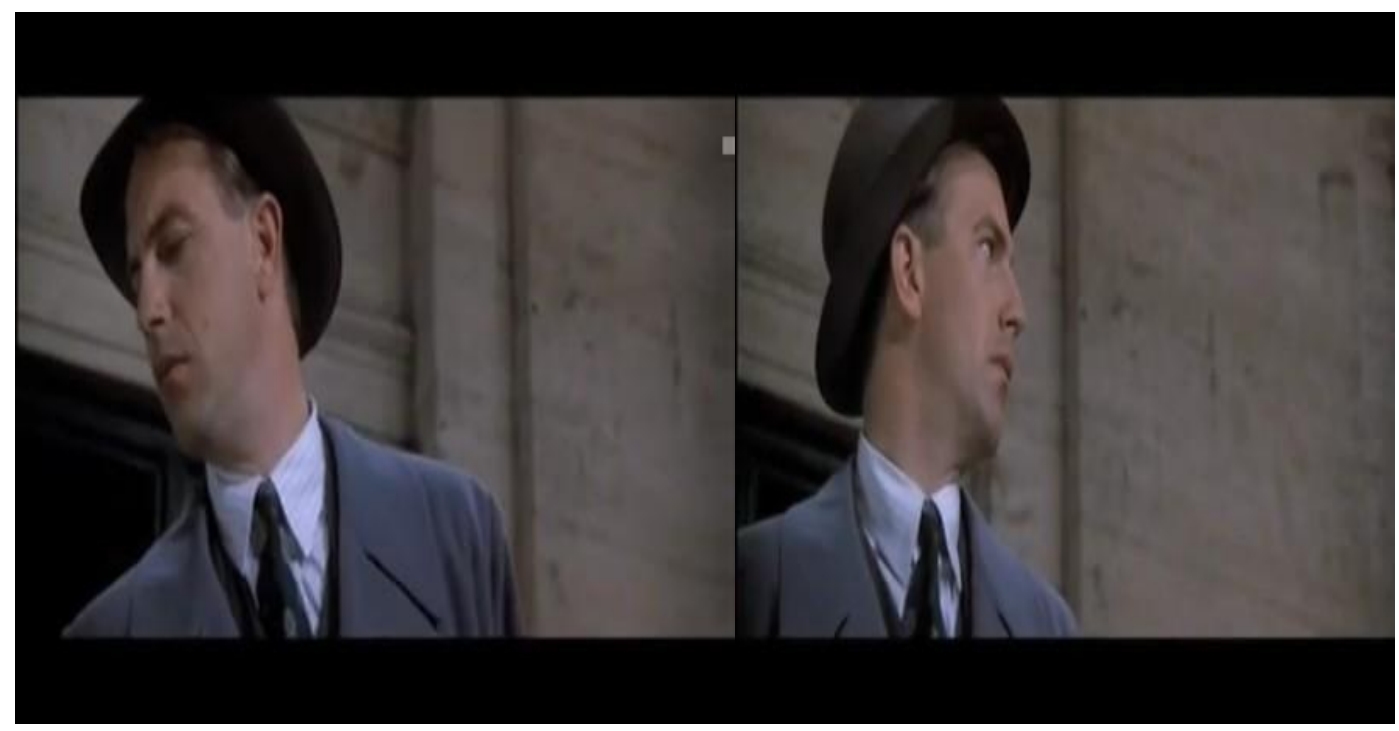

Esses dois operadores imprimem à cena, como um todo, semelhança à dramaticidade e à tensão da cena na escadaria de Odessa, aliados, porém, à tensão criada pela presença da mãe com o carrinho de bebê. Enquanto o tempo cronológico dá ritmo à narrativa, o tempo psicológico preenchido pela apreensão pelo que está prestes a acontecer alonga o tempo cronológico e o clímax da cena parece demorar para se concretizar. 
Os dois marcadores concretos do tempo cronológico não existem na escadaria de Odessa, mas aí o tempo é medido pelo número de corpos que caem, pela marcha sincronizada dos cossacos e pelo número sempre crescente de um corpo que cai.

Tem-se aí um efeito metafórico que se materializa com a estesia da cena. Esse efeito não é palpável, físico, mas dá o clima de tensão necessário ao conflito e, ao mesmo tempo, faz deslizar a tensão criada na montagem russa. Nesse sentido, falo de imaterialidades do ponto de vista da não concretude, do não visível, ${ }^{1}$ mas tacitamente significando em termos de materialidade discursiva. Importante, aqui, é também diferenciar o implícito, sempre explicitável e o tácito, que não pode ser explicitável e significa pelo silêncio.

\subsection{FATOR PROSÓDICO}

A materialidade sonora, em termos linguísticos, do grito da criança na escada "Matb! Matb!" (Mãe! Mãe!) - é transferida para a materialidade sonora do enunciado em inglês - "My baby!" (Meu bebê!) - dito pela mãe, jogada na escada. O movimento dos lábios do menino russo é imitado pela pronúncia descendente da frase "My ba by", ficando quase inaudível a última sílaba em inglês e igualando os dois enunciados quanto ao ritmo silábico.

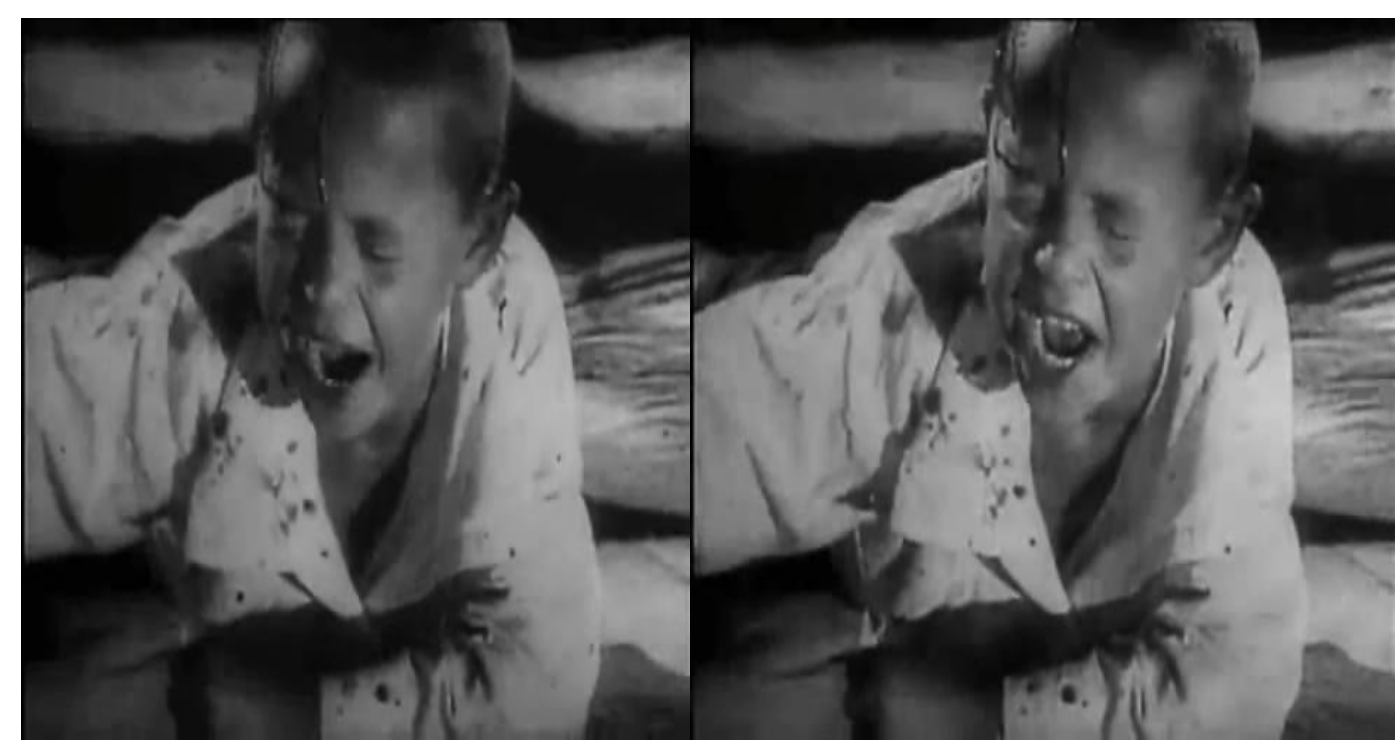

\footnotetext{
${ }^{1}$ Em Souza (2001, p. 72-73), argumento que “uma imagem não produz o visível; torna-se visível através do trabalho de interpretação e do efeito de sentido que se institui entre a imagem e o olhar."

Disponível em: http://seer.fclar.unesp.br/casa
} 
CASA, Vol.11 n.1, julho de 2013

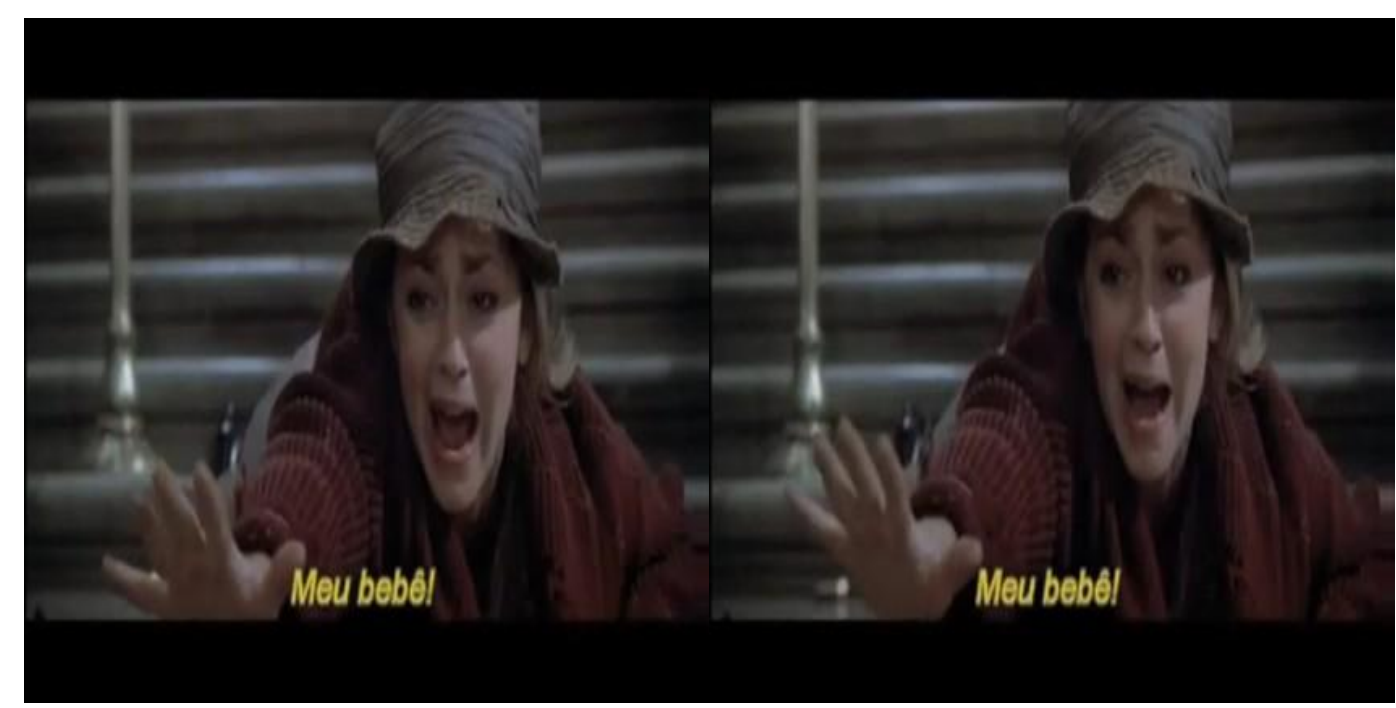

Em termos discursivos, mais uma vez, materializa-se um fato abstrato - a prosódia das duas línguas em compasso, apesar de os enunciados não se igualarem no significado, igualam-se no significante e traduzem o mesmo momento de angústia e sofrimento das duas situações.

Vale à pena, então, um parêntese para se pensar aqui os deslizamentos de sentido não verbais que se realizam não pela transferência de elementos de visibilidade propriamente ditos, mas sim pelos efeitos de sentido, no caso, toda a dramaticidade da cena que tais operadores produzem, pois estes são (i)materialidades visuais. Esse tipo de mecanismo reafirma, em termos de discursividade, o conceito de policromia acima referido, quando se pensa em rede de elementos visuais, implícitos ou silenciados.

\subsection{EXPRESSÃO FACIAL}

O desfecho da cena do bebê no carrinho na escadaria de Odessa é trágico: implicitamente, infere-se que o bebê é massacrado pela baioneta de um dos cossacos: o sangue espirra na face de uma mulher com o olhar terrificado.

Na cena da escadaria da estação do trem, o bebê é salvo, mas um dos personagens é morto a tiros: o sangue espirra na parede, e a expressão do personagem (o contador) ao lado do homem atingido pelo tiro se assemelha, em expressão, à cena de Odessa: são rostos aterrados - a mulher, pela dor que se instala ao presenciar o massacre do bebê; o homem, por ter escapado ileso no momento do troteio, quando um dos criminosos é atingindo. Reparem no grande plano que enquadra as duas faces carregadas de terror e sofrimento. Reparem, ainda, no detalhe dos óculos (parecidos na armação) e no deslocamento da mancha de sangue espirrado no rosto da mulher e ao lado do rosto do homem. O olhar de ambos reflete o terror. 


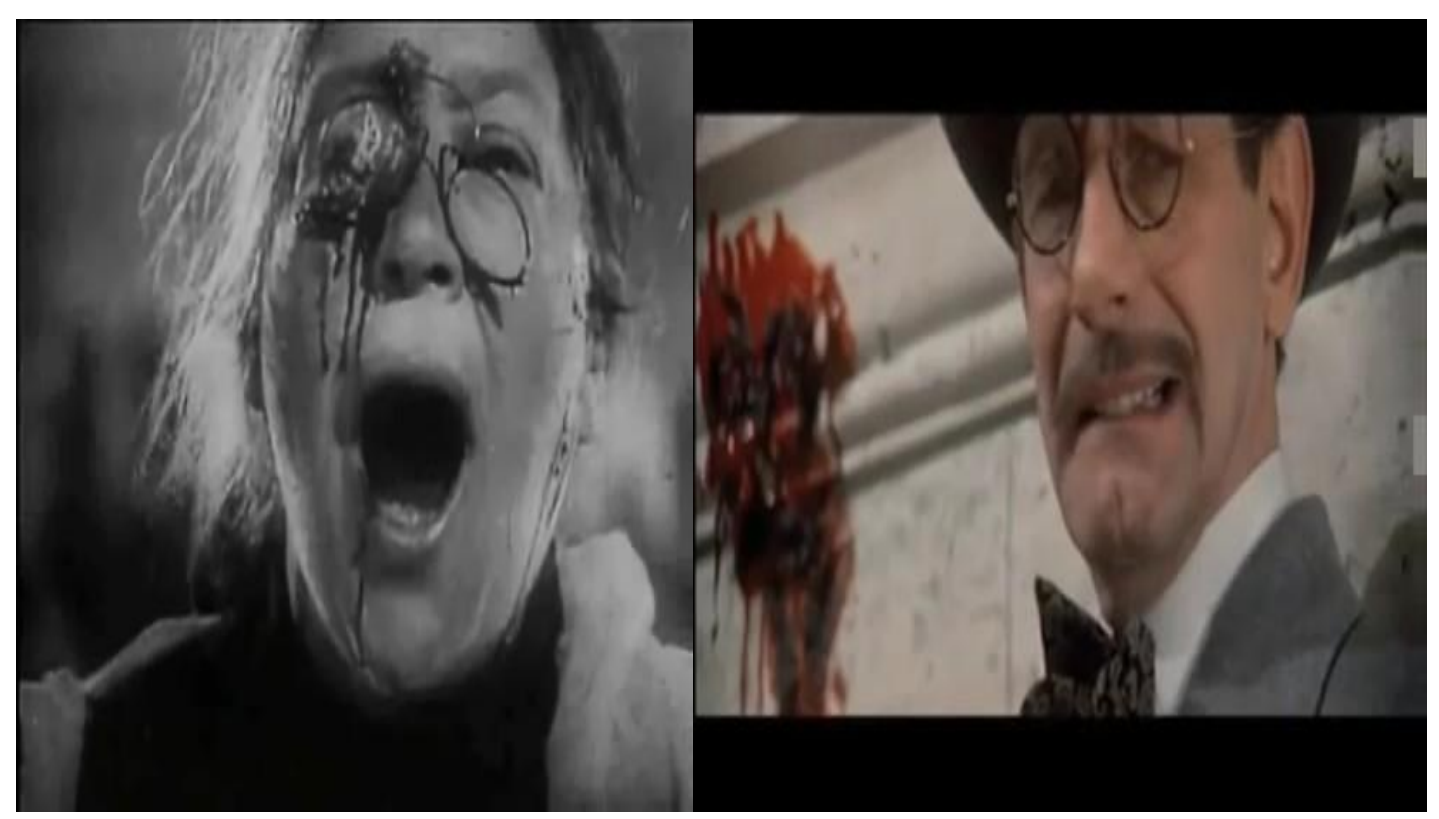

\subsection{RITMO DA CENA}

O vaivém de pessoas na escadaria da estação remete, em menor escala, ao movimento das pessoas na escadaria de Odessa. Os deslocamentos das personagens - a mãe, no lugar do bebê na escada, e o bebê, no carrinho - remetem, ao mesmo tempo, a dois episódios: à criança pisoteada na escadaria de Odessa e à mãe que é alvejada e, em desespero, vê o carro do bebê despencar. Com esse movimento, a cena na escadaria da estação de trem ganha em ritmo e em densidade dramática, pois sintetiza dois momentos trágicos do filme russo. Os operadores que aí funcionam são: o traje da mãe (chapéu e casaco iguais aos de uma das personagens na escadaria de Odessa), o mesmo plano nas rodas do carrinho de bebê e os mesmos gestos da mãe em diálogo com o bebê.

Os deslocamentos operados nessa ressignificação recortam as personagens de forma interessante: a posição dos braços da mãe na escadaria do trem se iguala aos gestos da criança que é pisoteada na escada em Odessa. O que se tem aí é uma mesclagem de vários personagens num só: o traje da mãe na escada é igual ao traje de uma personagem que apenas foge dos cossacos, não participando de nenhum evento em particular; é a mãe que ocupa o espaço na escada da estação de trem, mas com a mesma posição da criança pisoteada no filme russo. $\mathrm{Na}$ escadaria do trem, não há criança pisoteada, há apenas o bebê no carrinho que despenca pela escada. Logo transfere-se para uma só personagem tanto a dor da criança que agoniza na escada, quanto a mesma angústia das duas mães em Odessa: a da criança pisoteada e a outra que, uma vez alvejada, vê o carro do bebê despencar pela escadaria. $\mathrm{O}$ espectador, no entanto, que conheça as duas cenas relacionadas pode jogar com a visibilidade implícita resultante dessa mesclagem: o apagamento de eventos e de personagens significam pelo que não se mostra. Significam, mais uma vez, pela estesia impregnada numa cena, que recupera todos os efeitos de sentidos de uma série de cenas encadeadas, aqui referendadas por todos esses deslizamentos de operadores. 

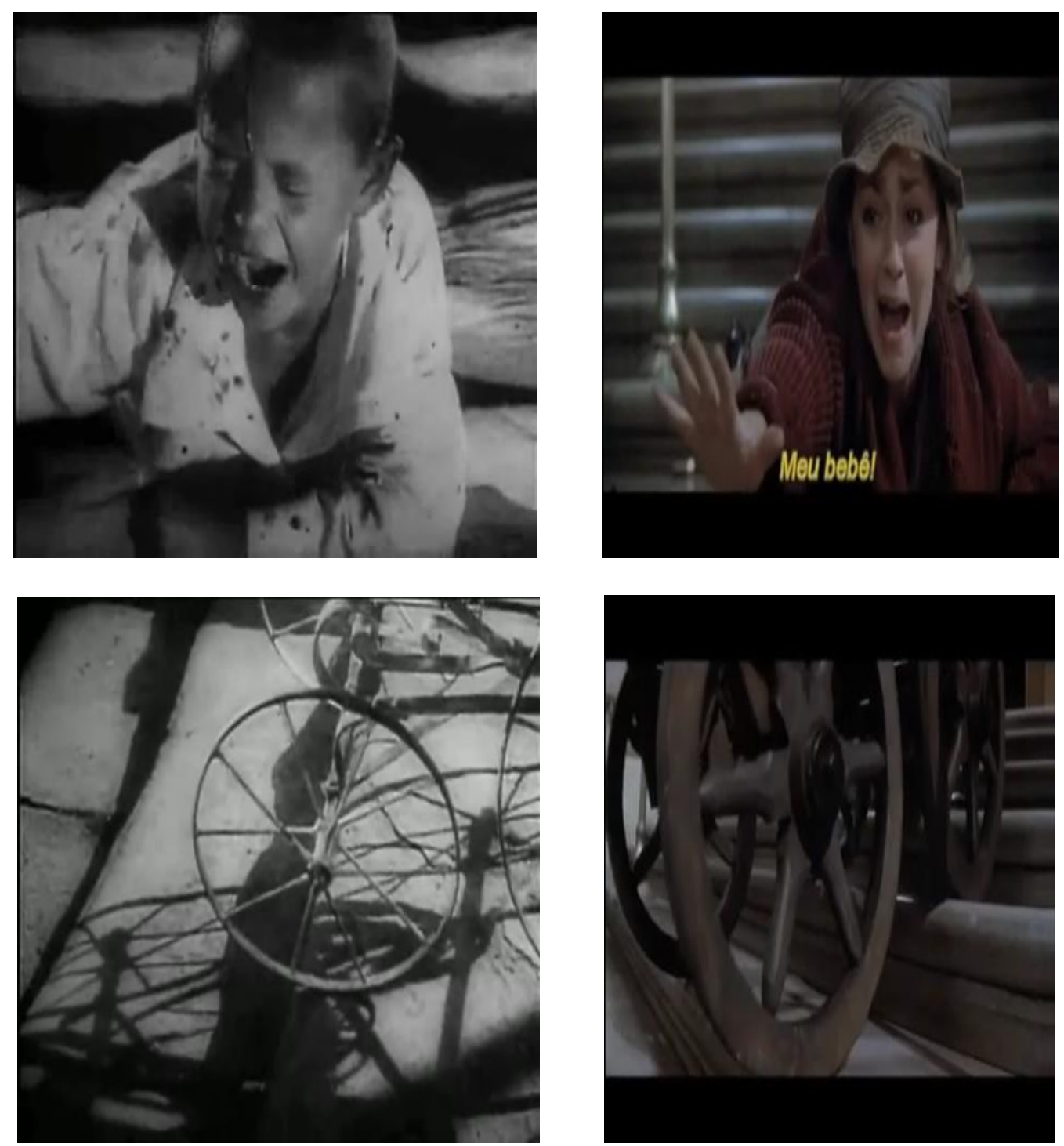

A função desses operadores, porém, não parece ser a de copiar os elementos cênicos do filme russo, e sim de poder transferir a mesma densidade dramática. Enfim, não significam pela relação forma/conteúdo, mas pelos efeitos metafóricos. Ou seja, metaforizase a tensão dramática e desloca-se a ação propriamente dita.

\subsection{VERTICALIDADE X HORIZONTALIDADE DOS CORPOS}

O retrato dos cossacos mostra fardas, armas e corpos sempre eretos. Parecem personagens sem vida, dada a frieza e a falta de qualquer reação diante dos fatos trágicos que se desenrolam. Essa postura contrasta com os corpos que tombam e se amontoam pelos degraus da escada. O número de personagens na escadaria da estação de trem é bem menor, mas observa-se um deslizamento interessante: dentre os passageiros que sobem as escadas para embarcar, estão alguns marinheiros fardados. ${ }^{2} \mathrm{O}$ filme de Eisenstein enfoca um motim,

${ }^{2}$ O filme narra a insurreição da tripulação do encouraçado "Príncipe Potemkin Tavritcheski", em junho de 1905. Os marinheiros Matiuchenko e Vakulintchuk preparam o plano de insurreição, utilizando indicações da organização clandestina revolucionária dos marinheiros militares do Mar Negro.

Disponível em: http://seer.fclar.unesp.br/casa 
provocado por dois marinheiros que acabam fuzilados, mas esses não participam da cena da escadaria. Embora, no filme de Plama, os marinheiros não sejam o alvo do policial, acabam sendo atingidos e tombam ensanguentados nos degraus da escada. Em termos de efeito metafórico, tem-se aí uma inversão na postura dos corpos: os homens de farda podem ser uma referência direta aos cossacos fardados que, na escadaria de Odessa, nunca se vergam, mas, na escadaria da estação de trem, os homens de farda são também massacrados. Assim, por um efeito metonímico, são as fardas que tombam, ou a ordem imposta pelas fardas, e não os marinheiros propriamente ditos.

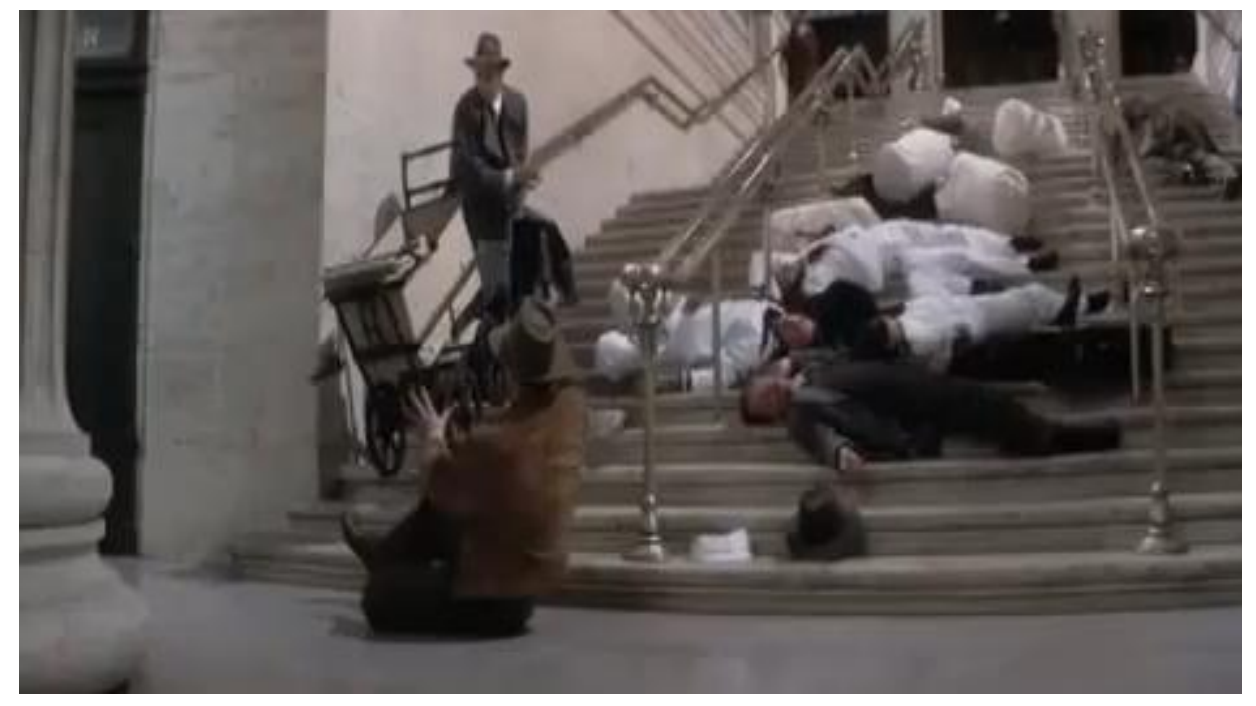

\section{Sobre sonoridade e sentido}

Com o advento do cinema sonoro, o som passou a ser, segundo Deleuze (1990), um dos componentes da imagem. No cinema mudo, o olhar cumpria duas funções: a de ver as imagens e a de ler os intertítulos que traduziam falas e até pensamentos dos personagens. Com o recurso do som, as imagens passam a ser "sonorizadas" ganhando, portanto, uma visibilidade outra. Em termos linguísticos, o autor traduz essa mudança como a passagem de um discurso indireto ${ }^{3}$ - "Ele diz que vai matá-lo" - para um discurso direto - "Vou matá-lo". A diferença entre esses dois momentos do cinema está, como propõe Deleuze, no fato de o cinema mostrar os acontecimentos, os objetos, a cidade, o apartamento etc. com uma naturalidade que é só deles. Residem, nessa naturalidade, o segredo e a beleza da imagem muda. "E, é verdade, ela [a imagem visual muda] envolve de tão perto os atos de fala que pode nos fazer ver as lamentações dos pobres ou o grito dos personagens." (idem).

O cinema mudo, porém, não era mudo, era apenas "silêncio", como diz Chion (1994). Desde o nascimento do cinema, pretendeu-se que o som estivesse unido às imagens. ${ }^{4}$ "O som pode moldar ativamente a forma como interpretamos a imagem", argumenta e, a partir daí, o autor elabora toda uma teoria sobre a relação som e imagem, elucidando os vários efeitos de sentido que decorrem dessa relação. O efeito de um som fixo, por exemplo, pode

\footnotetext{
${ }^{3}$ Deleuze toma a noção de discurso de Benveniste (1988), Problemas de Linguística Geral I, como aquele que enuncia ou reproduz falas, diferente da narrativa que conta os acontecimentos.

${ }^{4}$ Rick Altman, baseado em ampla documentação, afirma que, no ano de 1908, determinadas salas ofereciam, no espaço de um dia, exibições acompanhadas por ruídos, por vozes atrás da tela, por um comentador, por música executada ao vivo, e meramente por silêncio. Nesse sentido, argumenta que o cinema nunca foi só "silêncio".
} 
ser criado de forma variada ou evolutiva e repetido infinitamente, como em espiral. Como o traço de um movimento ou trajetória, o som tem, assim, sua própria dinâmica temporal. São três os aspectos que definem a temporalização, e que permitem entender a influência do som na percepção da imagem.

O primeiro aspecto abrange a animação temporal ${ }^{5}$ da imagem. Ao variar em níveis, o som transforma a percepção do tempo numa imagem exata, detalhada, imediata ou vaga, flutuante, ampla. No segundo aspecto, corrente no cinema mudo, certas tomadas nem sempre indicam sucessão temporal, onde o que acontece no quadro B seria aparentemente a sucessão do quadro A. Mas sons sincrônicos, de fato, impõem o efeito de sucessão. E, por fim, no terceiro aspecto, o som vetoriza ou dramatiza quadros, direcionando os mesmos em função de um objetivo determinado futuro, criando, assim, a sensação da iminência e a expectativa. A análise da sonoridade das duas cenas em questão ilustram, em grande alcance, esses três aspectos da sonoridade.

O filme de Eisenstein é mudo, entretanto, a sonoridade está lá significando a partir de vários movimentos. Em termos sonoros, uma trilha musical (uma sinfonia) funciona à feição de uma voz over se sobrepondo à narrativa. Há uma modulação em termos de velocidade, ritmo e densidade tonal em sincronia com as tomadas de cena. $\mathrm{O}$ close nos rostos aterrados e nos olhos esgazeados das pessoas, aliados ao movimento dos lábios e da contração dos rostos, fazem ecoar para o espectador os gritos silentes, sem realização sonora, mas que, dada o realismo das cenas, estão lá significando.

No entremeio da melodia, há ruídos que se igualam aos disparos das armas dos cossacos. Esses ruídos são sincronizados com a marcha dos cossacos, mostrada pelo plano detalhe nas botas; aos tiros se segue a queda muda dos corpos que rolam pouco a pouco pelos degraus. À medida que a dramaticidade da cena se avoluma, a sinfonia, em combinação com o som dos tiros, atende às "curvas" e movimentos daqueles instantes. Quanto mais as pessoas se apressam, em fuga daquele terror, mais o ritmo se acelera, indo de um movimento andante para alegro. Em alegro, a melodia alcança um pico estridente em altura no momento em que a criança é pisoteada. Há momentos de silêncio, de pausa, o ritmo fica ralentado passando de alegro, andante até lento, como é o caso em que a mãe pede ajuda para o filho ferido, e ambos acabam por ser exterminados. Todo esse trabalho sonoro se repete ao longo do filme. Aqui o efeito de sucessão de fatos atenderia a essa sincronia entre som (over) e os planos em close.

No filme de Brian de Palma, dada a possibilidade de grandes recursos tecnológicos (os sons se propagam em vários canais e simultaneamente, por exemplo), o plano da sonoridade é bem mais complexo. Há vários tipos de som que, além de estarem em sintonia com a narrativa, são sobrepostos uns aos outros reproduzindo com fidelidade as várias incidências de som no ambiente em que se desenrola a cena - o saguão da estação de trem. Assim, os sons ambientais reproduzem os passos dos passageiros em trânsito, ruídos de portas que abrem e fecham, o som da voz do alto-falante que anuncia a próxima partida do trem. Apesar de ambientais, esses sons têm papel na diegese do filme: os passos podem significar a chegada daqueles que o policial espreita; seu olhar procura alguém toda vez que se ouve esse som; a voz mecânica no alto-falante, metaforicamente, ao anunciar o embarque no expresso para $00.05 \mathrm{~h}$, anuncia também a iminência do embate. Tudo concorre para o suspense do momento. Tem-se, aqui, a discussão que Chion (idem) oferece a respeito do som como valor agregado, resultante da sincronia entre som e imagem.

Fundidos a esses sons, estão outros. Há duas melodias, a que perpassa a narrativa, semelhante à sinfonia presente no filme russo e uma canção de ninar suave, com

\footnotetext{
${ }^{5}$ Fundado no estudo do tempo, está o trabalho de Epstein, referendado por vários autores, incluindo-se Chion. Disponível em: http://seer.fclar.unesp.br/casa
} 
sons que lembram os de uma caixinha de música; o choro intermitente do bebê acalentado por pequenas frases sussurradas pela mãe. A cena, como um todo, é silente, há poucas falas, ouvese, apenas, um breve diálogo entre o policial e a mãe a partir do instante em que este se dispõe a ajudar com a subida do carrinho. $\mathrm{O}$ arranjo sonoro que, então, institui-se é composto como uma partitura. Ao mesmo tempo em que se ouve a canção de ninar e o choro do bebê, ouve-se a voz mecânica e um som de apito relativo à partida do trem; ouvem-se, mais uma vez, passos de pessoas em trânsito e, a partir de então, o barulho ritmado e compassado das rodas do carrinho subindo a escada, degrau por degrau. O movimento da subida é lento, enquanto o tempo cronológico está se esgotando - descompasso entre o movimento do tempo e o movimento da imagem/carrinho. Todo esse complexo sonoro tem função metafórica: os ruídos, ao mesmo tempo que significam o tempo cronológico, alimentam o clima de tensão e a expectativa em função do momento.

Para que o som temporalize as imagens, são necessárias determinadas condições. Os efeitos citados acima dependem de como se conjugam imagens, a um só tempo, com sons de determinada natureza para que o resultado almejado seja alcançado. Chion enumera duas condições em que som e imagem se conjugam. Vou me deter na segunda condição, aquela em que a própria imagem tem um movimento temporal. É quando se lida com a temporalidade do som conjugada à temporalidade presente na imagem as quais podem se mover em sintonia, ou ligeiramente em conflito entre si, como dois instrumentos tocando simultaneamente. O tique-taque mecânico do relógio na parede, por exemplo, parece ser traduzido pela sobreposição da canção de ninar e a voz mecânica do alto-falante.

A temporalização também depende do tipo de sons. A partir da densidade, da textura interna, da qualidade tonal e progressão, um som pode temporariamente implementar uma imagem em maior ou menor grau, ou com mais ou menos movimento, ou com um ritmo contido. Ou seja, fatores diferenciados contam na sustentação do som, na forma como um som progride com pulsação regular (como um baixo contínuo na música ou um "tique-taque" mecânico), ou como o próprio tempo se define. A temporalização também depende do modelo de ligação do som/imagem e da distribuição de pontos de sincronia, isto é, a extensão com a qual o som ativa uma imagem se dá na forma como são introduzidos esses pontos de sincronia, de forma previsível ou não, de forma variada ou não, ou de forma monótona. $\mathrm{O}$ controle da expectativa, da atenção interfere diretamente na temporalização. É o que se verifica com a análise a seguir no filme de Palma.

O tempo se esgota e começa o embate. Mais um descompasso: o carrinho, lentamente, desce degrau por degrau, marcado pelo mesmo ruído da subida. Cresce o conflito, policiais e bandidos trocam tiros. Os sons dos tiros se alternam com o som que acompanha o ruído do carrinho, referenciado pelo close nas rodas, em três ou quatro momentos. São sons temporais em conflito e assinalam os dois lados adversos do combate. Os tiros são interrompidos, ouve-se, por um breve instante, um pequeno trecho da canção de ninar, tem-se o silenciamento dos sons, instaura-se a discussão entre o policial e o bandido, que rende e ameaça o contador. O momento clímax da ação se dá entre o intervalo de silêncio e o tiro derradeiro. Volta a melodia over em tom crescente, coroando o excelente desfecho da ação.

Enfim, na cena da estação ferroviária, há a primazia do som, um valor agregado com papel diegético. Como se trata de um amplo saguão, os sons se reproduzem em eco, duplicando as espirais definidas em Chion. Na cena da escadaria de Odessa, há a primazia das vozes e dos gritos: estes, calados pela brutalidade dos cossacos; aquelas, silenciadas pelo terror que se instala no momento. Ambos os recursos - sonoridade e silêncio - têm um papel importante na temporalização da imagem quando, em termos de estesia, alongam o tempo cronológico e fazem perdurar a tensão (o tempo psicológico). 


\section{Moldura, tela e enquadres}

Aumont (2002) considera Eisenstein um criador de sistemas. No interior desse sistema, inventam-se os conceitos e, por consequência, nascem as teorias. "De todos os cineastas que abordaram a teoria, o mais sistemático, nesse sentido, é incontestavelmente Eisenstein: ele não cessou de teorizar". (idem: 43). Faz parte desse sistema - conjunto de conceitos - a teorização sobre montagem, discutida em vários momentos por Aumont e outros.

A montagem é descrita, antes de tudo, como uma atividade de ordem temporal, que ocupa a "quarta dimensão", a do tempo. A referência, aqui, é ao artigo de Eisenstein, que apresenta uma metodologia da montagem com base em uma tipologia: indo da mais simples à mais complexa, distingue cinco tipos a partir de relação buscadas entre planos sucessivos.

A montagem métrica recobre a organização dos planos segundo relações de duração bruta, mensuráveis e cronometradas. A montagem rítmica refina a métrica, contando, nesse processo, não a duração bruta, mas a duração sentida pelo espectador, a duração empírica e experienciada. A montagem tonal soma ao ritmo, quando, então, também se define outra qualidade, a música, igualmente metafórica. A sucessão de planos (fragmentos para Eisenstein) é montada para que o efeito seja a "sonoridade emocional". A montagem harmônica se constitui em refinamento da tonal. Sendo em si uma metáfora, Eisenstein a considera extremamente complexa, "que leve em conta todos os estímulos "emocionais", mesmo os mais tênues, os produzidos pelos detalhes mais sutis". (AUMONT, idem). Por fim, a montagem intelectual, transposição do modelo harmônico para fora do modelo puramente emocional. Nessa montagem, trabalham a conjunção de todos os aspectos dos planos duração, tonalidade, cor, potencial emotivo, detalhe cromático e harmônico. Enfim, uma construção que agrega todos os recursos da linguagem cinematográfica.

A análise da cena citada em Os intocáveis busca ilustrar o tipo mais complexo de montagem, a intelectual. A descrição do trabalho de sonorização apresentado acima contribui para essa colocação, além do que discutimos no item 3. Recorto, a seguir, alguns elementos que ilustram um pouco tal afirmativa, não me proponho, porém, a esgotar todos os elementos que caracterizariam a cena como montagem intelectual. De forma breve, pretendo explicitar como a referida cena significa para mim em termos discursivos.

A cena da escada da estação fica emoldurada pelas paredes pilastras, no caso, os limites do saguão da estação. A cena da escadaria de Odessa é aberta, não confinada, por isso se estende pela grande tela. Essas observações me levam a retomar Bazin (1991), Moldura e tela: o cinema e a arte. Na reflexão sobre a relação pintura e cinema, Bazin reflete sobre os efeitos de sentido presentes nos filmes sobre pintores e obras de arte. Afirma, junto com diferentes olhares críticos, que a estética numa obra de arte circundada por uma moldura difere da estética do filme quando a obra de arte é transposta para a grande tela. Segundo Bazin, a moldura do quadro, não funciona por ser mera função decorativa ou retórica, mas sim porque constitui uma zona de desorientação do espaço. Ao lado da natureza e de nossa experiência ativa que orla seus limites externos, opõe-se o espaço orientado do lado de dentro, o espaço contemplativo e somente aberto para o interior do quadro.

A tela destrói radicalmente o espaço pictural. Os limites da tela não são, como o vocabulário técnico daria a entender, a moldura da imagem, mas a máscara que só pode desmascarar uma parte da realidade. A moldura polariza o espaço para dentro, tudo o que a tela nos mostra, ao contrário, supostamente se prolonga indefinidamente no universo. A moldura é centrípeta, a tela é centrífuga. Consequentemente, invertendo-se o processo 
pictural, a tela é inserida na moldura, o espaço do quadro perde sua orientação e seus limites para impor-se à nossa imaginação como indefinido. Sem perder as outras características plásticas da arte, o quadro se encontra afetado pelas propriedades espaciais do cinema, ele participa de um universo virtual que resvala de todos os lados.

Pelo meu olhar, o funcionamento discursivo das duas cenas sob análise se dá numa tensão entre a moldura e a tela. A moldura, por sua força centrípeta, vetoriza o olhar do espectador para dentro da cena, retendo a permanência do olhar. O movimento de câmara que ora recorta o saguão da estação de trem, num plano geral, a partir do olhar insistente do policial para os ponteiros do relógio ao fundo, ora recorta (em plongée) sua apreensão, ao verificar a intervenção da mãe com o carrinho do bebê, aumenta a tensão, catalisando o suspense. Tem-se, então, a possibilidade de um espectador observador, até certo ponto passivo, atento ao desenrolar e desfecho do conflito, mas não enredado na trama, apesar de enlaçado pela narrativa. A tela, por sua força centrífuga, remete ao fora de campo, dá vazão ao próprio processo discursivo, constituindo todo um espaço de incompletude e de heterogeneidade do filme, capturando o espectador, envolvendo-o na trama por esse espaço de heterogeneidade (marcas visíveis do tu), ${ }^{6}$ possibilitado pelo extracampo e promovendo sua participação na ação dramática. Decorrem, daí, dois efeitos de sentido diferenciados: um efeito-ficção em de Palma e um efeito-realismo em Eisenstein, por isso duas reações diferentes no espectador. A tensão e o suspense prendem o espectador, mas não deixam escapar que o que se está vendo é ficção. O realismo promove a indignação, a partilha da dor e do sofrimento, ofuscando a fronteira entre o real e o representado. A repercussão de $O$ encouraçado Potemkim, como se fosse um documentário de fatos reais, decorre, a meu ver, dessa diferença de enquadre trazida pelo jogo entre moldura e tela.

Ainda sobre o enquadre, em ambas as cenas, os protagonistas - o policial e as pessoas que ocupam a escadaria - são recortados em contra-plongée. Esse ângulo privilegia o policial, conferindo-lhe uma dimensão de grandeza, de tranquilidade; apesar da situação em si, ele tem controle de tudo. O herói fica enaltecido ao assomar grandioso. Nasce o mito. $\mathrm{O}$ mesmo plano em Odessa recorta o povo descendo os degraus em atropelo, pisoteando uns aos outros. A dimensão, aqui, revela a grandeza do massacre, denuncia atos de um regime autoritarista sustentado pela submissão e frieza dos cossacos. A diferença entre esses dois sentidos advindos do mesmo tipo de plano está na produção de (i)materialidades discursivas: o ângulo materializa e engrandece a imagem (visível) do herói e dimensiona, pelo massacre do povo, não só a extensão do fato, mas também o jugo político (implícito) que instaura e licencia tal fato.

Todas as nossas observações apresentadas aqui nos permitem ratificar nosso objetivo primeiro: como se textualiza o político no âmbito do não verbal? Os gestos que dão visibilidade às duas famosas cenas são, em si, gestos que se assemelham na técnica de fazer significar os traços de visibilidade. São, porém, gestos discursivos que se diferenciam na forma de dizer o político no espaço da ficção. Estão em jogo duas posições discursivas conflituosas: uma que denuncia o acontecimento - o massacre -, e outra que faz do acontecimento - a cena-homenagem - uma autorreferência no bojo do fazer cinematográfico.

\footnotetext{
${ }^{6} \mathrm{O}$ conceito de heterogeneidade discursiva prevê marcas (mostradas ou não) no texto que assinalam o espaço do tu, reafirmando, assim, a dimensão dialógica da linguagem.
} 


\section{Conclusão: memória e político}

Em trabalhos anteriores, já discutimos o papel da imagem na constituição da memória. Em Souza (2006), por exemplo, ao analisar os trailers de divulgação no exterior do filme Cidade de Deus (2002), de Fernando Meireles, apontamos como o político pode se textualizar em imagens que, aliadas a outros recursos, têm a um só tempo a sua visibilidade apagada no intuito de dar corpo a uma memória da ordem do discurso, do ideológico. No caso dos trailers, buscamos explicitar que o silenciamento das imagens, decorrente da edição das peças de divulgação do filme, põe à mostra o jogo de relações de forças que subsidiam o imaginário social. O mito da visibilidade forja-se na relação do simbólico com o imaginário, sustentando o fato de que as "imagens falam por si", e projetando como naturais sentidos que, na verdade, são historicamente construídos por esse jogo de relações de forças. Pensamos a imagem como dispositivo e procuramos entender toda sua eficácia simbólica, o que coloca à mostra o seu papel de intervenção na construção da memória. (SOUZA, 2006).

No caso de Os intocáveis, o diretor anuncia sua intenção de homenagear o grande cineasta russo, entretanto não escapa à análise a memória discursiva que atravessa toda a tessitura do filme, em especial, a cena da escadaria. Em primeiro lugar, são flagrantes duas formações discursivas típicas do cinema americano: o maniqueísmo e o ufanismo.

O maniqueísmo ufanista elege um herói - naturalmente americano - que se coloca do lado do bem e está sempre disposto a salvar a humanidade. A declarada homenagem, em 1987, ao cineasta russo nos permite resgatar as noções de nacionalismo e patriotismo, discutidas em Bauman (2001). Na modernidade líquida, institui-se um tipo de patriotismo que se diferencia do nacionalismo, nem tanto pela questão retórica, mas por uma questão de prática política. O patriotismo, sendo o lado positivo da dupla nacionalismo/patriotismo, deixa o nacionalismo com suas realidades desagradáveis. $\mathrm{O}$ patriotismo descreve-se pela negação dos traços mais rejeitados e vergonhosos do nacionalismo. Trata-se de se pensar o patriotismo como sendo capaz "de inspirar estratégias antropofágicas (na terminologia de Lévi-Strauss), ou seja, devorar os estrangeiros, de modo que sejam assimilados pelo corpo de quem devora e se tornem idênticos às outras células deste, perdendo sua própria distintividade.” (BAUMAN, 2001, p.201). Para nós, insere-se aí a maestria do diretor do filme americano de trabalhar a montagem à altura do mestre russo. Já o nacionalismo "se associa mais à estratégia 'antropoêmica', de 'vomitar' e 'cuspir' aqueles que não estão 'aptos a ser nós', seja isolando-os por encerramento [...] dentro de muros de proibições culturais, seja cercando-os, deportando-os ou forçando-os a fugir, como na prática que recebe o nome de limpeza étnica." (BAUMAN, 2001, p. 201-202). Aqui funcionam os efeitos metafóricos de natureza ideológica operados pelos deslocamentos focados acima.

É nessa distinção nacionalismo/patriotismo que buscamos ver o trabalho da memória, tendo a imagem aí como intervenção. A retomada da cena da escadaria de Odessa traz à cena a atualização do embate ideológico plantado pela Guerra Fria: os cossacos aniquilam a todos, massacrando, inclusive, as criancinhas; já o policial americano só atinge os mafiosos e as fardas, sem perder de vista a missão de salvar o bebê. Todo o trabalho de textualização da cena da escadaria da estação ferroviária materializa discursivamente o fato histórico - a guerra ideológica, sem embate direto entre as duas maiores potências mundiais. E o manejo magistral da técnica de construção de imagens - seguindo os ensinamentos de Eiseinstein - bem como seus efeitos de sentido explicam como o complexo das relações em torno do "discurso e da figura" (cf.FOUCAULT, 2008) estão materialmente ligados pelo fio do político. 
Ao confrontar o dito - a vontade de homenagear o grande diretor russo, com as imagens - a retomada da cena da escadaria de Odessa, o cineasta americano não escapa ao interdiscurso (a memória do dizer), que atravessa sua posição discursiva, o que favorece recuperar nossa epígrafe: "Não é que a palavra seja imperfeita e esteja, em face do visível, num déficit que em vão se esforçaria para recuperar. São irredutíveis uma ao outro: por mais que se diga o que se vê, o que se vê não se aloja jamais no que se diz." (FOUCAULT, 1966, p. 25).

Quando assinalamos a forma como as imagens se textualizam, assinala-se também como se materializam os discursos, ou como trabalha a relação do real com o imaginário. Foi nossa intenção, ao analisar as marcas de textualidade da imagem, remetê-las à ordem do discurso e entender cada traço da textualidade não verbal como fato discursivo, enfim, como lugar de textualização do político.

\section{REFERÊNCIAS}

AUMONT, J. A estética do filme. São Paulo: Papirus Editora, 1995. . As teorias dos cineastas. São Paulo: Papirus Editora, 2010.

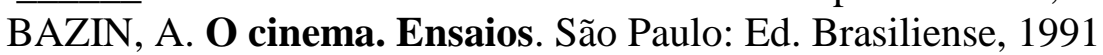

BAUMAN, Z. Modernidade líquida. Rio de Janeiro: Zahar, 2001

CHION, M. Audio-vision sound screen New York: Columbia University Press, 1990.

DELEUZE,G. A imagem-tempo. São Paulo: Ed. Brasiense, 1990

DUCROT. O. O dizer e o dito. São Paulo: Pontes, 1987

FOUCAULT, M. Les mots e les choses: une archéologie des sciences humaines. Paris: Gallimard, 1966

. Ditos e escritos II. Forense Universitária: Rio de Janeiro, 2008

ORLANDI, E. As Formas do Silêncio. Campinas: UNICAMP Editora, 1992

. Efeitos do verbal sobre o não verbal. Rua 1, Campinas: UNICAMP Editora, 1995

PÊCHEUX, M. Analyse automatique du discours. Paris: Maspero, 1969

SOUZA, T. C.C. de. Uma análise discursiva de Limite, In: AMÂNCIO, T. (org.) Limite de Mário Peixoto, CD-rom produzido LIA (Laboratório de Imagem e Áudio-visual), Rio de Janeiro: RIO Filmes, 1997

- Discurso e imagem: perspectivas de análise do não verbal, Conferência no $2^{\circ}$ Colóquio de Analistas del Discurso, Universidad del Plata, Instituto de Lingüística da Universidad de Buenos Aires, La Plata e Buenos Aires, 1997b (In: Ciberlegenda 1, Revista Eletrônica do Mestrado em Comunicação, Imagem e Informação, Niterói: UFF, 1998)

2000.

Carnaval e memória: das imagens e dos discursos, Contracampo 5, Niterói: UFF,

. A análise do não verbal e os usos da imagem nos meios de comunicação, Rua 7, Campinas: Pontes, 2001

. Discurso e imagem: uma questão política. IN: LENZI, L.H.C.; DA ROS, S.Z.; SOUZA, A.M. A. de.; GONÇALVES, M. M. (Org.). Imagem: intervenção e pesquisa, 1a. ed. Florianópolis: NUP, 2006, v. , p. 079-101

. Imagem, textualidade e materialidade discursiva In: RODRIUES, E. A. et al. Análise

de Discurso no Brasil: pensando o impensado sempre. Uma homenagem a Eni Orlandi.1 ed.Capinas: Editora RG, 2011

. O papel da imagem na constituição da memória. In: SILVA, T. da. et al (orgs.). Imagens na comunicação e discurso. São Paulo: Ed. Annablume, 2012. 